\title{
ОРГАНІЗАЦІЙНА СТРУКТУРА НАЦІОНАЛЬНОГО АГЕНТСТВА З ПИТАНЬ ЗАПОБІГАННЯ КОРУПЦІї
}

Продан А. 0.

Авторкою на основі детального аналізу вітчизняного антикорупційного законодавства, наукових та відомчих джерел визначено основний зміст понять «організація», «організаційна структура», розкрито особливості організаційних заходів, що отримали назву «перезапуск» Національного Агентства з питань запобігання корупції (далі - НАЗК). Зазначено, що завдяки зусиллям вітчизняного законодавця, громадських організацій й міжнародних інституцій в Україні вибудовано систему антикорупційних органів та затверджене їх правове забезпечення у подоланні корупційних проявів. Наголошено, що ефективна та успішна реалізація завдань та функцій цього центрального органу виконавчої влади зі спеціальним статусом, які покладені державою, безпосередньо залежить від належного рівня організаційного складника, що, врешті, й може забезпечити поступа льний розвиток спеціалізованого правоохоронного антикорупційного органу. Показано, що НАЗК має наразі оновлене правове забезпечення, що потягнуло за собою й зміну організаційної структури, зокрема, форми урядування НАЗК, перехід з колегіальної на одноосібну. Запропоновано організаційну структуру НАЗК розглядати як нормативно-закріплений перелік його підрозділів та територіальних органів, діяльність яких спрямована на виконання покладених на них завдань і функцій щодо реалізації ними державної антикорупційної політики.

Ключові слова: організаційна структура, запобігання корупчії, публічна влада, структурні підрозділи НАЗК, антикорупційна політика.

Автором на основе детального анализа отечественного антикоррупционного законодательства, научных и ведомственных источников изложено основное содержа ние понятий «организация», «организационная структура», раскрыты особенности организационных мероприятий, которые получили название «перезапуск» Начионального Агентства по вопросам предотвращения коррупции (далее НАПК). Отмечено, что благодаря усилиям отечественного законодателя, общественных организаций и международных институций в Украине выстроена система антикоррупционных органов и утверждено их правовое обеспечение в преодолении коррупционных проявлений. Отмечено, что эффективная и успешная реализация заданий и функций данного чентрального органа исполнительной власти со специальным статусом, который положен государством, непосредственно зависит от надлежащего уровня органи зационной составляющей, что в конечном итоге и может обеспечить поступательное развитие специализированного правоохранительного антикоррупционного органа. Предложено организационную структуру НАЗК рассматривать как нормативно-закрепленный перечень его подразделений и территориальных органов, деятельность которых направлена на выполнение возложенных на них заданий и функций относительно реализации ими государственной антикоррупционной политики.

Ключевые слова: организационная структура, предотвращение коррупции, публичная власть, структурные подразделения НАЗК, антикоррупционная политика.

Продан А. О., 2019
The author, based on a detailed analysis of national anti-corruption legislation, scientific and departmental sources, outlines the main content of the concepts of "organization", "organizational structure", reveals the features of organizational measures, called "restart" of Nation Agency on Corruption prevention (hereinafter - NACP). The opinions of local and foreign scientists on the concept of "organizational structure" are analyzed and it is concluded that this is an orderly set of permanent interrelated elements that ensure the functioning and development of the organization as a whole. It is proved that the effective and successful realization of the tasks and functions of this central executive authority with special status, which are assigned by the state, directly depends on the proper level of the organizational component, which in the end can ensure the progressive development of the specialized law enforcement anti-corruption authority. It is noted that thanks to the efforts of the local legislator, public organizations and international institutions, a system of anti-corruption authorities and their legal support in overcoming corruption manifestations has been established in Ukraine. It is emphasized that the effective and successful realization of the tasks and functions of this central executive authority with a special status, which are assigned by the state, directly depends on the proper level of the organizational component, which in the end can ensure the progressive development of the specialized law enforcement anti-corruption body. It is shown that the NACP has currently updated legal support, which has entailed a change in the organizational structure, including the form of governance of the NACP, the transition from collegial to sole. There is also a change in the organizational component of its functioning, including its accountability and control, the structure of the Agency, the procedure for appointing management, and so on. It is proposed to consider the organizational structure of NACP as a normative-fixed list of its units and territorial authorities, whose activity is aimed at fulfilling the tasks and functions assigned to them by the state anti-corruption policy.

Key words: organizational structure, corruption prevention, public authority, NACP structural divisions, anti-corruption policy.

Постановка проблеми та її актуальність. Розбудова України як суверенної і незалежної, демократичної, соціальної, правової держави передбачає формування та реалізацію власної національної стратегії і тактики розвитку усіх сфер життя громадян, державних інститутів і суспільства загалом. Завдяки цим засадничим заходам українській владі стане можливим забезпечити належний рівень національної безпеки країни, рівень життя як сучасного, так і майбутнього покоління населення, а також остаточно сформувати систему соціально-економічного розвитку країни.

Метою статті $\epsilon$ дослідження організаційної структури Національного агентства з питань запобігання корупції як передумови ефективного формування та реалізації державної антикорупційної політики в Україні. 
Виклад основного матеріалу. Запроваджені останніми роками реформи в різних сферах «життя країни» (зокрема, політичній, соціальній, економічній) зумовили як позитивні, так і негативні наслідки, до яких можна віднести: послаблення вертикалі державної влади, загрозливий для існування країни рівень корупції, зниження рівня життя населення, безробіття, поява загрозливих для національної безпеки країни політичних, релігійних, економічних протиріч серед населення тощо [1, с. 91].

Як бачимо, з поміж багатьох загрозливих для державності чинників вчені, практики й загалом суспільство виокремлюють корупцію, що, на думку експертів, проявляється в злочинному використанні службовими особами, громадськими і політичними діячами їх прав і посадових можливостей з метою особистого збагачення. Як і будь-яке суспільне явище, корупція в певних суспільних відносинах пронизує все суспільство, а в інших існувати не може. Таким чином, боротьба з корупцією може бути нічим іншим, як боротьбою за зміну суспільних відносин, які сприятливі для існування корупції, на суспільні відносини, в яких вона існувати не може. Сприятливими для існування корупції $\epsilon$ приватна власність і забюрократизованість системи державного правління. Дієвими підсилювачами боротьби з корупцією є заходи боротьби з корупціонерами. Згідно з макроекономічними та політекономічними дослідженнями корупція часто вважається чи не найбільшою перепоною до економічного зростання і розвитку, здатною поставити під загрозу будь-які перетворення [2; 3].

Варто наголосити, що в руслі наближення вітчизняного законодавства та запровадження відповідних соціальних стандартів країн Європейського союзу в Україні, починаючи з 2014 року було прийнято цілий пакет правових актів, норми яких зорієнтовані на запобігання та протидію корупції. Так, зокрема було створено систему антикорупційних органів, прототипи яких показали свою успішність у європейських країнах, як-от: Національне антикорупційне бюро [4], Національне агентство з питань запобігання корупції [5], Спеціалізована антикорупційна прокуратура [6], Державне бюро розслідувань [7], а в подальшому й Вищий антикорупційний суд [8]. Окрім цього, вітчизняним законодавцем у жовтні 2014 року було розроблено й прийнято антикорупційну стратегію [9] та внесено зміни до вже існуючих правових актів, зокрема до Кримінального кодексу України та Кодексу України про адміністративні правопорушення.

Як бачимо, завдяки зусиллям вітчизняного законодавця, громадських організацій й міжнародних інституцій в Україні вибудовано систему антикорупційних органів та їх правове забезпечення у подоланні корупційних проявів. До таких органів належить насамперед Національне агентство з питань запобігання корупції (далі - НАЗК).

Цілком закономірним $є$ той факт, що ефективна та успішна реалізація завдань та функцій зазначеного центрального органу виконавчої влади зі спеціальним статусом, які покладені державою, безпосередньо залежить від належного рівня організаційного складника, що, врешті, й може забезпечити поступальний розвиток спеціалізованого правоохоронного антикорупційного органу.

Варто наголосити, що НАЗК, як орган виконавчої влади, не функціонує самостійно, а тим паче ізольовано від інших органів гілок влади чи державного управління. Зважаючи на це, дослідження організаційної структури НАЗК $\epsilon$ досить важливим науковим напрямом, що потребує належної уваги як з боку науковців та експертів, так і парламентарів й державних службовців. Навіть більше, так званий «перезапуск» НАЗК, що проявився у реформуванні галузевого законодавства, передбачив зміну в організаційному складнику ії функціонування, зокрема, її підзвітність й підконтрольність, структуру Агентства, порядок призначення керівництва та інше.

На нашу думку, вказаний напрям дослідження забезпечить можливість проаналізувати зміст галузевого законодавства, дослідити основи матеріального й процесуального права та виробити відповідні пропозиції задля удосконалення адміністративно-правового статусу НАЗК.

Беручи до уваги напрацювання теоретиків права, наголосимо, що одним з початкових етапів дослідження теоретико-практичних проблем сучасного стану організаційної структури НАЗК має бути визначення безпосередніх інструментів методології наукового дослідження, а саме аналізу понятійного апарату. У нашому випадку йдеться про визначення понять «організація», «організаційна структура», «організаційна будова» та інших.

Доречно зазначити, що зазначеними вище поняттями досить часто послуговуються як теоретики, так і практики практично в усіх сферах життя. Разом з тим ці поняття не знайшли свого нормативного закріплення в актах, що регулюють діяльність органів публічної адміністрації, до яких відноситься й НАЗК. Хоча досить поширеною $€$ практика використання цих термінів у назві нормативних актів, як-от: Закон України «Про організації роботодавців, їх об'єднання, права і гарантії їх діяльності» від 22 червня 2012 р. [10], Наказ Генеральної прокуратури України, МВС України, СБУ, Адміністрації ДПС України, Міністерства фінансів України, Міністерства юстиції України від 16.11.2012 «Про затвердження Інструкції про організацію проведення негласних слідчих (розшукових) дій та використання їх результатів у кримінальному провадженні» та інше [11], Наказ МВС України від 26.01.2016 р. № 50 «Про затвердження Положення про організацію службової підготовки працівників Національної поліції України» [12] та інше.

Поширеним $\epsilon$ також використання у правових актах поняття «організаційна структура». Так зокрема, норми Господарського кодексу України визначають у ст. 64 «Організаційна структура підприємства» перелік виробничих структурних підрозділів (виробництв, цехів, відділень, дільниць, бригад, бюро, лабораторій тощо), а також функціональних структурних підрозділів апарату управління (управлінь, відділів, бюро, служб тощо), з яких можуть складатися відповідні підприємства [13].

Як бачимо, законодавець закладає в досліджувані нами поняття різний зміст, що свідчить про системний характер цих понять. Доречно наголосити, що і серед вчених немає єдиного підходу до визначення змісту вказаних понять.

Так, зокрема, на думку відомого вченого-правника Г.А. Туманова, поняття «організація» слід розглядати як поліструктурне поняття, що змушує розглядати поняття «організація» як юридичну категорію, а саме як певне структуроване соціальне утворення - орган державного управління, громадське формування, соціально-психо- 
логічну спільноту тощо; тоді як організацію в атрибутивному розумінні - як об'єктивну функцію управління, як його мету, засіб, результат; поняття «організація» в статиці - це фіксований, умовно стабільний стан складного об'єкта, об'єкта-системи; організація в динаміці - це елемент (стадія) послідовно здійснюваного процесу управління (управлінського циклу) [14, с. 42].

Дещо інший підхід до розуміння поняття «організація» був характерний для вітчизняного дослідника-правника Л.В. Коваля, який у розуміння поняття «організація» вкладав організовану колективну діяльність у притаманних їй формах управління і відповідних методах, актах. При цьому професор виокремлював три обставини, за яких доречним було використання поняття «організація», зокрема:

- організаціями можуть називатися державні, громадські, самоуправлінські органи, утворені для виконання будь-яких функцій державного або громадського характеру. У цьому значенні організація виступає соціальним інститутом із певним статусом;

- поняття «організація» - це явище, фактор, а відповідно, поняття і категорія, протилежні дезорганізації, невпорядкованості, невизначеності, хаосу;

- поняття «організація» може означати певну діяльність, що включає розподіл функцій, повноважень, обов'язків, налагодження сталих зав'язків, координацію тощо. Тут «організація» виступає як дії, процес, вплив [15, с. 19].

Дещо інший авторський підхід до розуміння сутності поняття «організація» проглядається в авторів підручника «Основи управління в органах внутрішніх справ», що підготовлений за редакцією професора О.П. Кор$\epsilon н \epsilon в а$. На їх (авторів) думку, поняття «організація» слід розглядати в двох смислових значеннях:

- по-перше, як упорядкований стан управляючої системи, об'єкта управління, тобто їх внутрішня структура (організація в статиці);

- по-друге, як функцію процесу управління або стадію управлінської діяльності (організацію в динаміці) [16, с. 188].

Така позиція дослідників управління в органах внутрішніх справ була підтримана свого часу й професором В.М. Плішкіним в процесі підготовці ним підручника «Теорія управління органами внутрішніх справ». Зокрема, вітчизняний вчений наголошував, що на практиці немає організації без структури, оскільки відсутність самих елементів або взаємозв'язків між ними не дозволяє говорити про наявність єдиного цілісного утворення, тобто системи. Організаційна структура соціальної системи - це, по суті, організаційна форма розподілу праці щодо прийняття (вироблення) та реалізації управлінських рішень [17, с. 173].

Разом з тим наукові погляди вищевказаних вчених-адміністративістів не були підтримані дослідником державного управління професором Г.В. Атаманчуком, який зазначав, що поняття «організація»- це:

- по-перше, формальне явище, створене шляхом виділення з будь-якого цілого його певної частки з метою покладення на неї (частину) адекватних функцій цілого;

- по-друге, взаємодія елементів частини як усередині, так і поза нею з метою реалізації покладених на неї функцій цілого;

- по-третє, стійка (за часом та в просторі) взаємодія елементів, що надає частині певні контури та укрі- плює їх за допомогою спеціалізації та кооперації можливостей цих елементів.

Таке твердження вченого базується на розумінні ним поняття «організація» як певної динамічної конструкції, тобто «організовувати» означає розташовувати людей у просторі (територія, споруди) та у функціональних (соціальні ролі, види робіт) координатах, з'єднувати їх засобами та знаряддями праці, забезпечувати їх взаємодію та взаємообмін у праці та громадському житті, розширювати ї можливості шляхом узгодження та концентрації зусиль [18, с. 190-191].

Певний підсумок наукових позицій щодо поняття «організація» здійснив вітчизняний дослідник С.І. Губков, наголосивши, що поняття «організація» охоплює багато аспектів: по-перше, створення, реорганізацію організаційних структур управління, тобто зміни в організаційній формі управління; по-друге, організуючий вплив суб'єкта на об'єкт управління з метою впорядкування та взаємодії елементів системи управління; по-третє, діяльність, що забезпечує здійснення процесу управління, тобто прийняття та реалізація управлінських рішень [19, с. 63].

Як бачимо, змістове навантаження досліджуваних понять свідчить про те, що організаційна структура кожного органу публічної влади, в тому числі й НАЗК, визначається певними об'єктивними факторами, ігнорування яких створює небезпеку для формування органу, установи, апарату, не здатних функціонувати в інтересах системи управління. Дляправильноїпобудови організаційних структур будь-якого органу публічної адміністрації необхідно знати фактори, які зумовлюють наявність у даних структурах тих чи інших елементів, зав'язків [20, с. 68].

Щодо факторів, які впливають на характер організаційних структур, то їх, на думку С.В. Кувакіна, поділяють на: безпосередні (цілі, завдання, функції, принципи та методи управління) та опосередковані (кадри, техніка, технологія управління, організація праці) [21, с. 44].

Близьким, але дещо ширшим за розумінням поняття «організаційна структура» бачить О.С Виханський, зокрема зазначає, що це впорядкована сукупність постійних взаємопов'язаних елементів, які забезпечують функціонування і розвиток організації як єдиного цілого. Ключовими поняттями структури управління $\epsilon$ елементи, зв'язки, повноваження та її рівні. Елементами організаційної структури можуть бути як окремі працівники, так і служби або органи апарату управління, в яких зайнята певна кількість спеціалістів, що виконують відповідні функціональні обов'язки [22].

Таким чином, попередньо можемо констатувати, що організаційна структура як поліутворення включає в себе відповідні структурні підрозділи (сектор, відділення, відділ, управління, департамент), що об'єднані між собою переліком завдань та функцій на основі вертикальних та горизонтальних зв'язків.

Як наголошує професор С.О. Кузніченко, в усіх органах публічної адміністрації, залежно від характеру виконуваних завдань та функцій, $є$ три види структурних підрозділів:

а) галузеві підрозділи - забезпечують реалізацію основних напрямів публічного адміністрування відповідного органу публічної адміністрації;

б) функціональні (кадрові, фінансово-економічні, господарчі, методичні), які виконують завдання та функції забезпечення; 
в) загального керівництва [23, с. 96-97].

Що стосується зв'язків організаційної структури НАЗК, то, на нашу думку, їх варто поділити на види, що мають:

- організаційно-предметний характер та виникають між працівниками відповідних підрозділів з приводу використання ними різних засобів під час реалізації ними повноважень;

- організаційно-функціональний характер, такі взаємозв'язки між працівниками підрозділів НАЗК за ступенем їх участі в спільній професійній праці;

- організаційно-адміністративний характер, що зумовлений субординацією працівників, тобто зв'язки владно-підвладного характеру.

Отже, організаційну структуру НАЗК доцільно розглядати як нормативно-закріплений перелік підрозділів НАЗК та його територіальних органів, діяльність яких спрямована на виконання покладених на них завдань і функцій щодо реалізації ними державної антикорупційної політики.

Варто наголосити, що організаційна структура НАЗК та його територіальних органів визначена i офіційно затверджена Законом України «Про запобігання корупції» від 14 жовтня 2014 р. [5], а також відомчими актами Агентства. При цьому організація НАЗК та їі територіальних органів базується на системі їі підрозділів, які перебувають між собою у певному управлінському зв'язку, що передбачає формування вертикальних відносин, а також комунікації та взаємозв'язку з іншими органами публічної адміністрації.

Наявна в НАЗК організаційна система включає в себе відповідні ієрархічні рівні:

1) керівний склад НАЗК, а саме: Голову, заступників Голови, керівника апарату НАЗК, заступник керівника апарату, керівники департаментів, управлінь, відділів, секторів, а також керівники територіальних органів;

2) систему структурних підрозділів (департаменти (координації антикорупційної політики; організації роботи із запобігання та виявлення корупції; моніторингу дотримання законодавства про конфлікт інтересів та інших обмежень щодо запобігання корупції; перевірки декларацій та моніторингу способу життя; з питань запобігання політичній корупції), управління, відділи, сектори, а також територіальні органи);

3) консультативні, дорадчі та інші допоміжні органи і служби (комісії, в тому числі конкурсні, колегії, робочі групи та інше);

4) апарат НАЗК, а також територіальних органів.

Для з'ясування змісту та особливостей організаційної структури НАЗК та його територіальних органів проаналізуємо більш детально названі нами вище рівні.

Першим (керівним) рівнем НАЗК є його керівництво, як-от: Голова, заступники Голови, керівник апарату, заступник керівника апарату, керівники департаментів, управлінь, відділів, секторів, а також керівники територіальних органів. Відповідно до норм Закону України «Про запобігання корупції» Національне агентство у межах, визначених цим та іншими законами, $\epsilon$ відповідальним перед Верховною Радою України і підконтрольним їй та підзвітним Кабінету Міністрів України органом. При цьому Національне агентство утворюється Кабінетом Міністрів України відповідно до Конституції України, цього та інших законів України.
Керівництво діяльністю Національного агентства здійснює його Голова, який призначається на посаду та звільняється з посади Кабінетом Міністрів України В порядку, визначеному цим Законом. Голова НАЗК призначається строком на чотири роки. При цьому одна і та ж сама особа не може обіймати посаду Голови Національного агентства два строки підряд. Повноваження Голови Національного агентства припиняються Кабінетом Міністрів України достроково у випадках, визначених Законом.

Що стосується порядку проведення конкурсного відбору та призначення Голови Національного агентства, то згідно зі ст. 6 Закону Голова Національного агентства призначається відповідно до результатів відкритого конкурсного відбору, чим власне й забезпечується прозорість його призначення. Організацію та проведення конкурсного відбору здійснює Конкурсна комісія з відбору на посаду Голови Національного агентства.

Як визначив законодавець (ч. 6 ст. 5 Закону), Голова Нацагентства може мати трьох заступників, яких він призначає на посаду та звільняє з посади. Заступники здійснюють свої повноваження відповідно до розподілу обов'язків, затвердженого Головою Національного агентства, та у разі відсутності Голови виконують його обов'язки відповідно до наказу Голови Агентства [5].

Аналізуючи повноваження Голови Агентства, зазначимо, що аналіз галузевого законодавства, наукової та довідкової літератури з даної проблематики дає можливість зробити висновок, що закріплені у Законі України «Про запобігання корупції» права та обов'язки спрямовані на виконання здебільшого адміністративної (організаційної), контрольної, забезпечувальної та юрисдикційної функцій.

Реалізацію адміністративної (організаційної) функції забезпечує виконання Головою Агентства таких повноважень:

1) організовує та контролює роботу Національного агентства, несе персональну відповідальність за законність, прозорість та ефективність діяльності Національного агентства, звітує про роботу Національного агентства;

2) призначає на посади та звільняє з посад працівників Національного агентства;

3) присвоює службовцям Національного агентства ранги державних службовців, вживає заходів заохочення, а також притягає службовців Національного агентства до дисциплінарної відповідальності згідно 3 рішенням дисциплінарної комісії Національного агентства;

4) розподіляє обов'язки між заступниками Голови Національного агентства;

5) приймає в установленому порядку рішення про розподіл бюджетних коштів, розпорядником яких $\epsilon$ Національне агентство;

6) затверджує штатний розпис та кошторис Національного агентства, положення про територіальні органи Національного агентства;

7) затверджує перспективні, поточні та оперативні плани роботи Національного агентства, визначає показники ефективності діяльності Національного агентства;

8) представляє Національне агентство у відносинах із судами, іншими державними органами, органами місцевого самоврядування, громадськими об'єднаннями, 
підприємствами, установами і організаціями, а також органами іноземних держав, міжнародними та іноземними організаціями тощо;

9) вживає заходів із запобігання несанкціонованому доступу до інформації з обмеженим доступом, забезпечує додержання законодавства про доступ до публічної інформації, розпорядником якої $\epsilon$ Національне агентство, та захист персональних даних, володільцем яких $\epsilon$ Національне агентство;

10) видає у межах повноважень накази та доручення;

11) має право бути присутнім на засіданнях Верховної Ради України, їі комітетів, постійних, тимчасових спеціальних та тимчасових слідчих комісій, а також брати участь з правом дорадчого голосу у засіданнях Кабінету Міністрів України, інших державних органів та органів місцевого самоврядування у разі розгляду питань, пов'язаних з формуванням та реалізацією антикорупційної політики;

12) здійснює інші повноваження відповідно до цього та інших законів [5].

Голова Нацагентства на реалізацію контрольної функції забезпечує виконання таких повноважень:

- здійснює контроль за розробкою та реалізацією планів основних заходів щодо реалізації державної антикорупційної політики;

- організовує контроль за виконанням закріплених у законодавстві заходів структурними підрозділами;

- забезпечує дотримання працівниками Національного Агентства норм галузевого законодавства України;

- в межах своїх повноважень спрямовує діяльність структурних підрозділів та територіальних органів Національного Агентства [5].

Окрему частину своїх повноважень Голова реалізує в межах забезпечувальної функції:

- вживає заходів щодо забезпечення проведення функціональної підготовки працівників Національного Агентства;

- забезпечує створення здорових, безпечних умов праці, дотримання працівниками правил охорони праці, техніки безпеки та пожежної безпеки.

Голова Агентства реалізацію юрисдикційної функції забезпечує виконанням таких повноважень:

- в межах наданих прав та у встановленому порядку готує пропозиції щодо заохочення працівників Національного Агентства, його територіальних органів;

- визначає в межах наданих повноважень ступінь відповідальності працівників Агентства.

Особливим елементом організаційної структури Національного Агентства $€$ Апарат, який здійснює організаційне, інформаційно-довідкове та інше забезпечення його діяльності. Положення про апарат Національного агентства і його структура, а також положення про самостійні структурні підрозділи апарату, затверджуються Головою Національного агентства. Гранична чисельність працівників апарату Національного агентства затверджується Кабінетом Міністрів України за поданням Голови Національного агентства.

Відповідно до ст. 8 Закону керівник апарату та його заступники призначаються та звільняються Головою Національного агентства, інші працівники апарату (крім працівників, які виконують функції з обслуговування або займають посади патронатної служби) призначаються за результатами відкритого конкурсу, крім випадку переведення в порядку, визначеному Законом України «Про державну службу».

На особливу увагу заслуговує присутність у складі організаційної структури Агентства підрозділ внутрішнього контролю, а також підрозділ з питань запобігання корупції Національного агентства.

Щодо функціонального призначення підрозділу внутрішнього контролю, то він забезпечує питання доброчесності працівників Національного агентства, а також забезпечення дотримання цього Закону в апараті Національного агентства. Рішенням Голови Національного агентства підрозділи внутрішнього контролю можуть створюватися також у територіальних органах Національного агентства.

Доречно наголосити, що порядок діяльності та повноваження підрозділів внутрішнього контролю визначаються положенням, яке затверджує Голова Національного агентства. Голова Національного агентства призначає на посади та звільняє з посад керівника та працівників підрозділу внутрішнього контролю. Беручи до уваги вищезазначене, підрозділи внутрішнього контролю підпорядковуються безпосередньо Голові Національного агентства.

На виконання своїх функціональних завдань підрозділ внутрішнього контролю Національного агентства:

1) здійснює моніторинг та контроль за виконанням працівниками Національного агентства актів законодавства з питань етичної поведінки, запобігання та врегулювання конфлікту інтересів, інших вимог, обмежень та заборон, передбачених цим Законом;

2) проводить контроль своєчасності подання та повну перевірку декларацій осіб, уповноважених на виконання функцій держави або місцевого самоврядування, що подаються працівниками Національного агентства, в порядку, визначеному Головою Національного агентства;

3) проводить перевірки працівників Національного агентства на доброчесність та моніторинг їхнього способу життя в порядку, визначеному Головою Національного агентства;

4) перевіряє інформацію, що міститься у зверненнях фізичних або юридичних осіб, засобах масової інформації, інших джерелах, у тому числі отриману через спеціальну телефонну лінію, сторінку в мережі Інтернет, засоби електронного зв'язку Національного агентства, щодо причетності працівників Національного агентства до вчинення правопорушень;

5) проводить службове розслідування стосовно працівників Національного агентства;

6) проводить спеціальну перевірку стосовно осіб, які претендують на призначення на посади в Національному агентстві;

7) вживає заходів щодо захисту працівників Національного агентства, які повідомляють про вчинення протиправних дій чи бездіяльність інших працівників Національного агентства;

8) виконує інші повноваження, визначені Положенням про підрозділ.

В апараті Національного агентства діє також підрозділ з питань запобігання корупції, положення про який затверджує Голова Національного агентства.

Підрозділ з питань запобігання корупції Національного агентства:

1) консультує працівників Національного агентства з питань дотримання вимог актів законодавства з питань 
етичної поведінки, запобігання та врегулювання конфлікту інтересів, інших вимог, обмежень та заборон, передбачених цим Законом;

2) організовує роботу з оцінки корупційних ризиків у діяльності Національного агентства, підготовки заходів щодо їх усунення та вживає інших заходів, спрямованих на запобігання вчиненню працівниками Національного агентства корупційних та пов'язаних з корупцією правопорушень;

3) розробляє та забезпечує реалізацію антикорупційної програми Національного агентства;

4) виконує інші повноваження, визначені Положенням про підрозділ з питань запобігання корупції Національного агентства.

Як свідчить аналіз організаційної структури НАЗК, відомство працює за 5-ма напрямами (без регіональних відділень). При цьому, за даними НАЗК, профільні департаменти $\epsilon$ неповними за чисельністю працівників, що свідчить про ймовірну недостатню ефективність функціонування відомства. Так, КМ України своєю Постановою «Про внесення змін до постанов Кабінету Міністрів України від 14 серпня 2013 р. № 703 та від 5 квітня 2014 р. № 85» від 30 березня 2016 року № 244 затвердив склад апарату НАЗК у кількості 311 осіб. Разом з тим наразі у складі НАЗК працює 213 осіб, що становить 68\% від загальної кількості затвердженого апарату. Водночас, як наголошують вітчизняні експерти, у Державній програмі щодо реалізації засад антикорупційної політики в Україні (Антикорупційної стратегіï) на 2015-2017 роки одним із заходів визначено забезпечення високого кадрового потенціалу апарату НАЗК, здатного виконувати на належному рівні свої завдання, зокрема: формування складу апарату НАЗК не менш, ніж на $90 \%$ до 1 січня 2016 р.

Як бачимо, наразі вимога Антикорупційної стратегії залишається невиконаною, а штат НАЗК - неукомплектованим, що своєю чергою, як ми вже наголошували, ускладнює виконання агентством своїх повноважень у повному обсязі.

Висновки. Таким чином, можемо констатувати, що НАЗК має наразі оновлене правове забезпечення, що потягнуло за собою й зміну організаційної структури, зокрема, форми урядування НАЗК, перехід з колегіальної на одноосібну. Окрім цього, гарантії незалежності Голови НАЗК забезпечено через визначення вичерпного переліку підстав для дострокового припинення його повноважень, які не передбачають можливості політично мотивованого звільнення. Прописано також зміну порядку формування та розширення повноваження Громадської ради при НАЗК (громадський контроль за діяльністю НАЗК забезпечуватиметься через Громадську раду при Агентстві, яка складатиметься з 15 осіб та формуватиметься відповідно до результатів відкритого конкурсу). Передбачено проведення кожні 2 роки зовнішньої незалежної оцінки ефективності діяльності Агентства [24]. Отже, зміст цих організаційних заходів зорієнтований на оновлення адміністративно-правового статусу НАЗК як інструменту держави у запобіганні корупції, формуванні в суспільстві культури доброчесності та нульової терпимості до будь-яких проявів корупції.

\section{Література}

1. Бодунов Є.Р. Публічне адміністрування іноземного інвестування в Україні : дис. ... канд. юрид. наук : 12.00.07. Київ, 2013. 219 с.

2. Bardhan P. Corruption and development. Journal of Economic Literature. 1997. Vol. 25. Р. 1320. [1] Архівовано 20 вересень 2009 у Wayback Machine. (англ.)

3. Tanzi, V. Corruption, Governmental Activities and Markets. IMF Working Paper 94/99. International Monetary Fund, Washington, DC. 1994. [2] (англ.)

4. Закон України «Про Національне антикорупційне бюро України» від 14 жовтня 2014 р. ВВР, 2014, № 47, ст. 2051.

5. Закон України «Про запобігання корупції» від 14 жовтня 2014 р. ВBP, 2014, № 49, ст. 2056.

6. Наказ Генеральної прокуратури України «Про Положення про Спеціалізовану антикорупційну прокуратуру Генеральної прокуратури України» від 12 квітня 2016, № 149. URL: https://zakon.rada.gov.ua/rada/show/ v0149900-16/print.

7. Закон України «Про Державне бюро розслідувань» від 12 листопада 2015 року. ВВР, 2016, № 6, ст. 55.

8. Закон України «Про Вищий антикорупційний суд» від 7 червня 2018 р. ВВР. 2018, № 24, ст. 212.

9. Закон України «Про засади державної антикорупційної політики в Україні» від 14 жовтня 2014 р. (Антикорупційна стратегія) на 2014-2017 роки. ВBP, 2014, № 46, ст. 2047.

10. Закон України «Про організації роботодавців, їх об'єднання, права і гарантії їх діяльності» від 22 червня 2012 р. BBP, 2013, № 22, ст. 216.

11. Наказ Генеральної прокуратури України, МBC України, СБУ, Адміністрації ДПС України, Міністерства фінансів України, Міністерства юстиції України від 16.11.2012 «ПрозатвердженняІнструкціїпроорганізаціюпроведення негласних слідчих (розшукових) дій та використання їх результатів у кримінальному провадженні» та ін. URL: https://zakon.rada.gov.ua/laws/show/v0114900-12.

12. Наказ МВС України від 26.01.2016 р. № 50 «Про затвердження Положення про організацію службової підготовки працівників Національної поліції України». URL: https://zakon.rada.gov.ua/laws/show/z0260-16.

13. Господарський кодекс України від 16 січня 2003 р. BBP. 2003, № 18, ст. 144.

14. Туманов Г.А. Организация как функция государственного управления. Советское государство и право. 1986. № 1. С. 38-46.

15. Коваль Л.В. Адміністративне право України : [навч. посіб.]. Київ : Основи, 1994. 154 с.

16. Основы управления в органах внутренних дел : [учебн.] / Н.И. Буденко, Г.П. Герт, В.Р. Кисин, Б.П. Кондратьев и др. / Под ред. А.П. Корнеева. Москва : Щит-М, 1996. 343 C.

17. Плішкін В.М. Управління органами внутрішніх справ : [навч. посіб.]. Київ : Національна академія внутрішніх справ України, 1996. 500 с.

18. Атаманчук Г.В. Теория государственного управления : Курс лекцій / Г.В. Атаманчук. Москва : Омега-Л, 2010, 528 с.

19. Губков С.І. Адміністративно-правові засади діяльності вибухотехнічних підрозділів експертної служби МВС України : дис. ... канд. юрид. наук : 12.00.07. Сімферополь, 2011. 200 с.

20. Погиба Павло Павлович. Адміністративно-правовий статус місцевих державних адміністрацій в Україні. Дисертація канд. юрид. наук : 12.00.07, Держ. ВН3 «Запоріз. нац. ун-т» М-ва освіти і науки України. Запоріжжя, 2015. 202 c. 
21. Кувакін С.В. Організаційні форми управління ОВС : загальнотеоретичний аспект : дис... канд. юрид. наук / Кувакін Сергій Вікторович. Харків, 2001. 197 c.

22. Виханский О.С. Стратегическое управление: учебник / О.С. Виханский. 2-е изд. перераб. и доп. Москва : Гардарика. 1998. С. 106.

23. Кузніченко С.О. Управління органів внутрішніх справ в особливих умовах, викликаних аномальними явищами техногенного і природного характеру : [моногр.].
Харків : Вид-во Національного університету внутрішніх справ, 2001. 170 с.

24. Набрав чинності Закон про перезапуск HA3K//https://jurliga.ligazakon.net/ua/news/190222_nabravchinnost-zakon-pro-perezapusk-nazk.

Продан А. О., аспірантка кафедри адміністративного права Київського національного університету імені Тараса Шевченка 